\title{
日本の難聴者におけるストレスと精神的健康の実態 12
}

\author{
難聴・難聴者への理解を深めるために \\ 勝谷紀子 \\ (青山学院大学) \\ キーワード : 難聴, ストレス, 精神的健康
}

\begin{abstract}
Stress and mental health of hearing-impaired people in Japan
Noriko KATSUYA

(Aoyama Gakuin University)
\end{abstract}

Key Words: hearing impairment, stress, and mental health

\section{目 的}

「全壟の作曲者」佐村河内守氏の作品がゴーストライター によるものだったことが発覚した。また，佐村河内氏は全壟 ではなく，身体障害者手帳の取得に至らないレベルの感音性 難聴であることも検査によって判明し, 身体障害者手帳を返 還する事態となった。これら一連の事態の報道には，身体障 害者手帳の取得に至らない難聴者は聴覚障害ではないかのよ うな詋った内容，壟ではない難聴者は日常生活では支障がな いかのような䛊解を与えかねない内容も含まれていた。

よって, 日本における難聴や難聴者一の誤解や偏見をなく すために難聴者の実態を明らかにし，難聴や難聴者に関する 知識を専門家でなくても誰でも知っている常識にするための 対策を考える必要がある。そこで本研究では, 難聴者を対象 に調查を行い，ストレスと精神的健康の実態を調べた。

\section{方 法}

調査対象者 一般社団法人全日本難聴者 - 中途失聴者団体 連合会 (全難聴) の加盟協会に所属する難聴者 453 名（男性 139 名, 女性 312 名, 不明 2 名, 平均年齢 65.22 歳)。

調査手続き 加盟協会に対して会員への調查票の配布を依 頼した。各会員には，回答済みの調査票を郵送で返送するよ うに求めた（協力の了承を得た回答者に第 2 回調查を実施し たが，ここでは報告しない)。

調査票の構成 調査票の質問は, 大きく分けて基本的属性, 聞こえの状態, 精神的健康, 身体的健康に関わる質問からな つていた。本報告では, 精神的健康に関わる項目を報告する。

精神的健康の指標 CES-D（島・鹿野・北村 ・浅井, 1985) によって抑うつを調べた。また，難聴者への聞き取り調査に もとづき作成した難聴にまつわるストレスイベント尺度によ ってストレスイベントの経験の有無と経験した場合の辛さ

（(1) 全く辛くなかった-(5)非常に辛かった，の5 段階，35 項目）を尋㸚た。数值データの分析にはR3.1.0 を用いた。

\section{結 果}

聞こえの状態について 回答者のうち，聴覚障害による身 体障害者手帳を持っている者は 389 名, その他の障害によっ て手帳を持つ者が 9 名，身体障害者手帳を持っていない者は 48 名（無回答 7 名）だった。難聴のタイプについては，感音 性難聴が 307 名, 伝音性難聴が 19 名, これら両方の混合型が 85 名, 不明が 28 名, その他が 14 名だった（複数回答）。

精神的健康の指標の傾向 CES-D の合計得点の平均值は 14. $14(S D=8.32)$ だった。難聴にまつわるストレスイベント尺 度の回答については,「経験した」と回答した割合が多かった 項目は，日常生活の様々な場面に関わるものだった（表 1 )。

身体障害者手帳の有無による比較 精神的健康の指標につ いて, 身体障害者手帳の有無や手帳の等級によって違いがあ るかを検討した。まず, CES-D の合計得点を比較したところ, 聴覚障害による身体障害者手帳を持っている回答者

( $M=14.13)$ と身体障害者手帳を持っていない回答者 $(M=13.70)$ とで差がみられなかった $(t(38.25)=.268, n . s$.$) 。$

また，難聴にまつわるストレスイベント尺度について，「経
験した」と回答した項目の数を比較したところ, 聴覚障害に よる身体障害者手帳を持っている回答者 $(M=28.07)$ は持って いない回答者 $(M=25.15)$ より数が多かった $(t(59.26)=2.575$, $p<.05)$ 。辛さの評定值の合計点については，聴覚障害による 身体障害者手帳を持っている回答者 $(M=108.99)$ が持っていな い回答者 $(M=90.33)$ よりも有意に高く評定していた $(t(57.92)$ $=2.83, p<.01)$ が，等級による差はみられなかった。

\begin{tabular}{|c|c|c|}
\hline 番号 & 項目 & 経験率 \\
\hline 7 & $\begin{array}{l}\text { 声の小さな人や早口の人の話が聞き取りにくかった } \\
\text { (もしくは、聞こえなかった) }\end{array}$ & 95.50 \\
\hline 18 & テレビやラジオの音声が聞きとりにくかった & 94.48 \\
\hline 8 & $\begin{array}{l}\text { 遠くから話しかけられて聞き取りにくかった(もしくは、 } \\
\text { 聞こえなかった) }\end{array}$ & 93.05 \\
\hline 19 & $\begin{array}{l}\text { 駅、建物内 (デパートやイベント会場など) の放送が聞 } \\
\text { きとりにくかった(もしくは、聞こえなかった) }\end{array}$ & 92.97 \\
\hline 27 & マスクをかけた人の声が聞きとりにくかった & 92.95 \\
\hline 20 & $\begin{array}{l}\text { 電車やバスなど乗り物内の放送が聞きとりにくかった } \\
\text { (もしくは、聞こえなかった) }\end{array}$ & 92.79 \\
\hline 21 & $\begin{array}{l}\text { マイクやスピーカー越しの音声がわかりにくかった(も } \\
\text { しくは、わからなかった) }\end{array}$ & 92.78 \\
\hline 9 & 周囲が静かでない場所での会話が聞き取りにくかった & 92.74 \\
\hline 4 & $\begin{array}{l}\text { 受付、窓口、レジでの会話が聞き取りにくかった(もしく } \\
\text { は、聞こえなかった) }\end{array}$ & 92.12 \\
\hline
\end{tabular}

注：経験率が 90\%を超えた項目のみを示している。

\section{考 察}

日本の難聴者におけるストレスと精神的健康の実態を調心゙ た。今回の調査協力者は, 聴覚障害関係の協会に所属してい る難聴者であった。自身の聞こえの問題についてある程度自 覚あるいは受容をしており, 何らかの対処をしようと取り組 む動機づけが高い可能性が考えられる。聞こえの問題を自覚 できない，あるいは明らかにせずに抱え込む難聴者もいると 思われることから, 今後は協会に所属をしていない難聴者も 対象として比較，検討することが必要である。

\section{引用文献}

島 悟 - 鹿野達男 - 北村俊則・浅井昌弘（1985）新しい抑う つ性自己評価尺度について 精神医学 27, 717-723.

1 調査実施, データ整理には山本真菜さん, 川久保美奈さん, 西村光一さんにご協力いただきました。また, 調査の実施に は全難聴および加盟協会の皆様の支援を受けました。記して お礼を申し上げます。

2 本研究は JSPS 科研費 23730669 の助成を受けたものです。 